\title{
LIFE CYCLE ASSESSMENT IN BUILDING MATERIALS. THE NEED FOR CHANGE IN EU LEGISLATION
}

\author{
Aguta Elena Teodora ${ }^{1}$ \\ Dorin Radu ${ }^{2}$ \\ Radu Mircea Muntean ${ }^{3}$
}

UDK: 691:349.442

DOI: $10.14415 /$ konferencijaGFS2019.047

Summary: Life cycle assessment is increasingly being used worldwide to quantify the environmental performance of buildings, set impact reduction targets, and ensure a safe environment for future generations. In building material sector there are specific regulations adopted by the European Union. However, there are differences in the level of enactment for different EU member countries. The present paper underlines the need for new regulations in the building materials, considering the sustainability approach in this filed.

Keywords: life cycle assessment, sustenability, building materials

\section{INTRODUCTION}

Life-cycle assessments (LCAs) involve cradle-to-grave analyses of production systems and provide comprehensive evaluations of all upstream and downstream energy inputs and multimedia environmental emissions. LCAs can be costly and time-consuming, thus limiting their use as analysis techniques in both the public and private sectors. Streamlined techniques for conducting LCAs are needed to lower the cost and time involved with LCA and to encourage a broader audience to begin using LCA. It has emerged as a valuable decision-support tool for both policy makers and industry in assessing the cradle-to-grave impacts of a product or process. Two forces are driving this evolution. First, government regulations are moving in the direction of "life-cycle accountability;" the notion that a manufacturer is responsible not only for direct production impacts, but also for impacts associated with product inputs, use, transport, and disposal. Second, business is participating in voluntary initiatives which contain LCA and product stewardship components. Together these developments have placed LCA in a central role as a tool for identifying cradle-to-grave impacts both of products and the materials from which they are made [3].

LCA approach had its beginnings in the 1960's. Concerns over the limitations of raw materials and energy resources sparked interest in finding ways to cumulatively account

\footnotetext{
${ }^{1}$ Aguta Elena Teodora, student at University Transilvania of Braşov, Faculty of Civil Engineering

${ }^{2}$ Dorin Radu, PhD, Lecturer at University Transilvania of Brașov, Faculty of Civil Engineering

${ }^{3}$ Radu Mircea Muntean, PhD, Lecturer at University Transilvania of Brașov, Faculty of Civil Engineering
} 
Савремена достигнућа у грађевинарству 23-24. април 2019. Суботица, СРБИЈА

for energy use and to project future resource supplies and use. In one of the first publications of its kind, Harold Smith, reported his calculation of cumulative energy requirements for the production of chemical intermediates and products at the World Energy Conference in 1963 [1].

From 1975 through the early 1980's, as interest in these comprehensive studies waned because of the fading influence of the oil crisis, environmental concerns shifted to issues of hazardous and household waste management. However, throughout this time, life cycle inventory analysis continued to be conducted and the methodology improved through a slow stream of about two studies per year, most of which focused on energy requirements

When solid waste became a worldwide issue in 1988, LCA again emerged as a tool for analysing environmental problems. As interest in all areas affecting resources and the environment grows, the methodology for LCA is again being improved. A broad base of consultants and researchers across the globe has been further refining and expanding the methodology. The need to move beyond the inventory to impact assessment has brought LCA methodology to another point of evolution (SETAC 1991; SETAC 1993; SETAC 1997).

Between 1997 and 2002 after some developments that took place to the 14000 series the LCA methodology was standardized in the International Standard Organization(ISO).” [2]. The publication of these first international standards of LCA was an important milestone for the application of LCA and an essential step to consolidate procedures and methods.

\section{LIFE CYCLE ASSESSMENT LEGISLATION IN EUROPEAN UNION}

International standards for LCA were developed since the 90's as part of the ISO 14000 family of environmental management standards.

ISO 140402006 and ISO 140442006 are the core standards of LCA that are still valid today. The current ISO 14040 is a framework and guidance standard, while ISO 14044 contains all technical requirements and guidelines on these. Therefore, ISO 14040 provides a more general, introductory reading of the concept and outline of LCA including its principles. For the LCA practitioner, ISO 14044 is the operational document including all requirements for ISO compliant LCA studies. This section is by no means able to replace reading the actual standard documents. It is rather intended to give a flavor of the key features of the standards and supposed to proselytize those who so far resisted the core standards of LCA.

According with ISO 14040 there are four linked components of LCA [3] [2]:

Goal definition and scoping: identifying the LCA's purpose and the expected products of the study, and determining the boundaries (what is and is not included in the study) and assumptions based upon the goal definition;

Life-cycle inventory: quantifying the energy and raw material inputs and environmental releases associated with each stage of production;

Impact analysis: assessing the impacts on human health and the environment associated with energy and raw material inputs and environmental releases quantified by the inventory; 
Contemporary achievements in civil engineering 23-24. April 2019. Subotica, SERBIA

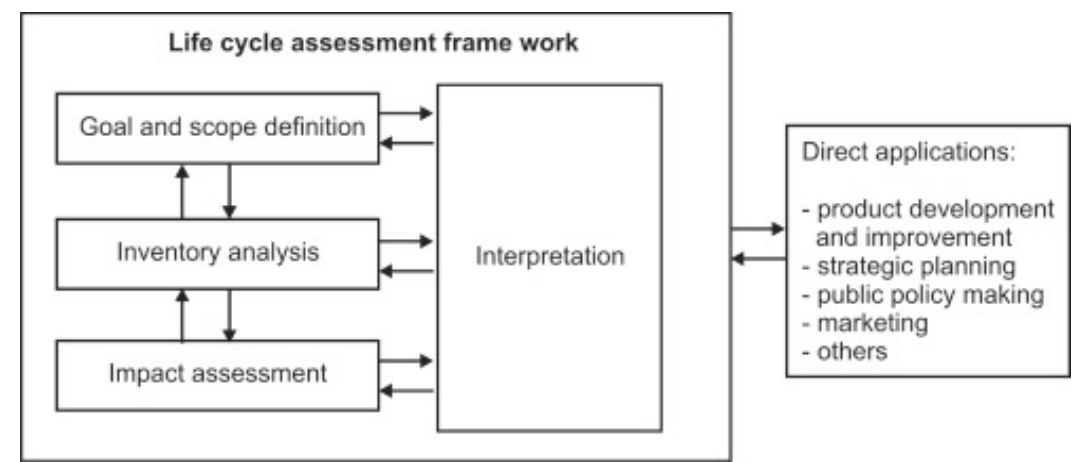

Figure.1 - LCA stages under the ISO 14040 guidelines [5]

Improvement analysis: evaluating opportunities to reduce energy, material inputs, or environmental impacts at each stage of the product life-cycle.

LCA helps decision-makers select the product, process, or technology that results in the least impact to the environment. This information can be used with other factors, such as cost and performance data to find optimal solutions. LCA identifies the transfer of environmental impacts from one media to another (for instance: a new process may lower air emissions, but creates more wastewater, etc.) and between different lifecycle stages. The diagram in figure 2 illustrates the main lifecycle stages to be considered in the life cycle assessment.

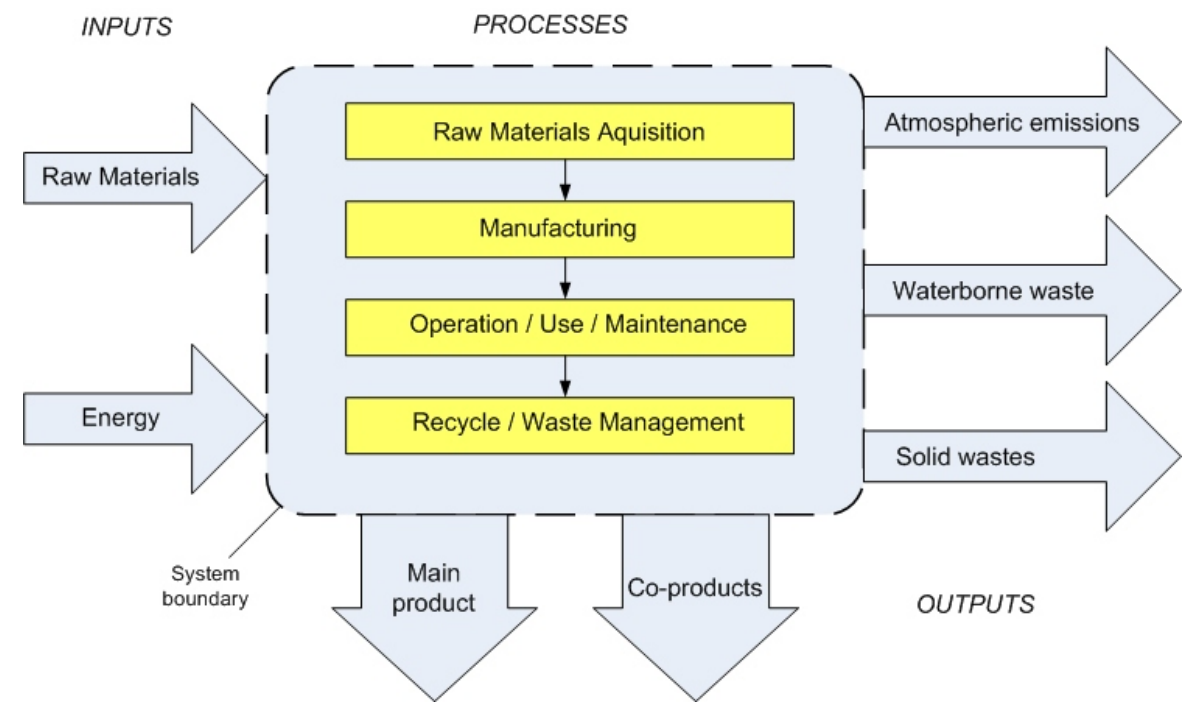

Figure 2 - Main stages and typical inflows and outflows considered in lifecycle assessment [4] 
Life cycle assessment in European Union is applied according to the following standards/normatives:

- $\quad$ EN ISO 14021:2016 Environmental labels and declarations -Self-declared environmental claims (Type II environmental labelling). As a description, this normative specifies requirements for self-declared environmental claims, including statements, symbols and graphics, regarding products. It further describes selected terms commonly used in environmental claims and gives qualifications for their use.

- EN ISO 14024:2018 Environmental labels and declarations -- Type I environmental labelling - Principles and procedures. It establishes the principles and procedures for developing Type I environmental labelling programmes, including the selection of product categories, product environmental criteria and product function characteristics, and for assessing and demonstrating compliance. ISO 14024:2018 also establishes the certification procedures for awarding the label.

- EN ISO 14025:2010 - Environmental labels and declarations -- Type III environmental declarations -- Principles and procedures. This standard establishes the use of the ISO 14040 series of standards in the development of Type III environmental declaration programmes and Type III environmental declarations.

- $\quad$ EN ISO 14031:2014 - Environmental management -- Environmental performance evaluation - Guidelines. This norm gives guidance on the design and use of Environmental Performance Evaluation (EPE) within an organization. It is applicable to all organizations, regardless of type, size, location and complexity.

- EN ISO 14044: 2007. Environmental management. Life Cycle Assessment. Requirements and guidelines. It specifies requirements and provides guidelines for life cycle assessment (LCA) including: definition of the goal and scope of the LCA, the life cycle inventory analysis (LCI) phase, the life cycle impact assessment (LCIA) phase, the life cycle interpretation phase, reporting and critical review of the LCA, limitations of the LCA, relationship between the LCA phases, and conditions for use of value choices and optional elements.

- $\quad$ EN ISO 14045: 2012 Environmental management. Assessing the eco-efficiency of product systems. Principles, requirements and guidelines. This standard describes the principles, requirements and guidelines for eco-efficiency assessment for product systems including: the goal and scope definition of the eco-efficiency assessment; the environmental assessment; the product-system-value assessment; the quantification of eco-efficiency; interpretation (including quality assurance); reporting; critical review of the eco-efficiency assessment.

- ISO/TS 14048:2002 Environmental management. Life Cycle Assessment. Format of the data documentation. This is a technical specification which provides the requirements and a structure for a data documentation format, to be used for transparent and unambiguous documentation and exchange of Life Cycle Assessment (LCA) and Life Cycle Inventory (LCI) data, thus permitting consistent documentation of data, reporting of data collection, data calculation and data quality, by specifying and structuring relevant information.

- $\quad$ EN 15804 + A1: 2014. Sustainable development of construction works. Product environmental statements. Basic rules for the category of construction products.

- EN 15942: 2012. Sustainability of construction works. Environmental product declarations. Communication format business-to-business. 
Contemporary achievements in civil engineering 23-24. April 2019. Subotica, SERBIA

- $\quad$ EN ISO 14040:2007 - Environmental management — Life cycle assessment Principles and framework

\section{LCA LEGISLATION IN BUILDING SECTOR}

Being one of the biggest consumer of materials and nonrenewable energy, the construction sector became a very important subject when talking about the entire cycle of a structure (mostly the materials used in the process) from the extraction of raw materials to disposal and it's negative effects over the environment. In order to reduce them, it must be considered the aspects of sustainability concept through a sustainable development. Life Cycle Assessment (LCA) is thought of as being the best tool for assessing sustainability in construction industry.[6]

The need of applying the sustenability approach in building field, imposed a reglementations in labeling of the poducts. Thus appeared the concept od ECO labelling. The EU Ecolabel is an evaluation/communication instrument developed by the European Commission during the last 20 years to support 'business to consumers' environmental initiatives. Ecolabel is a 'Type I' environmental label, according to the ISO 14020 classification and is intended to be a voluntary market tool for promoting environmental excellence in products and services in a rigorous and standardised way.

The scientific reliability of the EU Ecolabel is based on the use of the life cycle assessment methodology (LCA) for establishing the environmental criteria used in assessing products.

In practice, the EU aims to break down the link between economic growth and environmental degradation. To this end, several strategies have been proposed and remain under continuous improvement:

- promotion of environmental innovations at industrial level;

- promotion of information about environmental friendly technologies;

- encouragement of green public procurement;

- developing and promoting the Ecolabelling of products and services.

The environmental labels (identified as 'Type I' by ISO 14020) and the environmental product declarations (or EPD, identified as 'Type III' by ISO 14025) are tools that enable the identifycation of products or services which offer reliable information on environmental impact throughout their life cycle, from the extraction of raw material through production, use and disposal. However, the EU Ecolabel differs from the EPD as it guarantees environmental excellence as defined by the European Commission.

The construction and building materials sector can only be partially affected by the EU Ecolabel. It is therefore important to make information available about the products used in construction and the general construction criteria and management which will minimise environmental impact in terms of resources consumed, emissions and waste produced during the operational life of the structure.

The traceable product and service groups belonging to this sector are:

- coverings (wooden, hard, textiles);

- indoor and outdoor paints and varnishes;

- tourist accommodation;

- office buildings;

- road construction;[2] 
Савремена достигнућа у грађевинарству 23-24. април 2019. Суботица, СРБИЈА

In the open market there are an increasing number of Ecolabel associations (figure 3), many of them having the same role in the declaration of the ECO friendly of a material. Thus it appears the need of standardize and group of the associations in order to have a clear legislation in the authorization process - in the future normatives there is the need of imposing new / environmentally friendly materials.
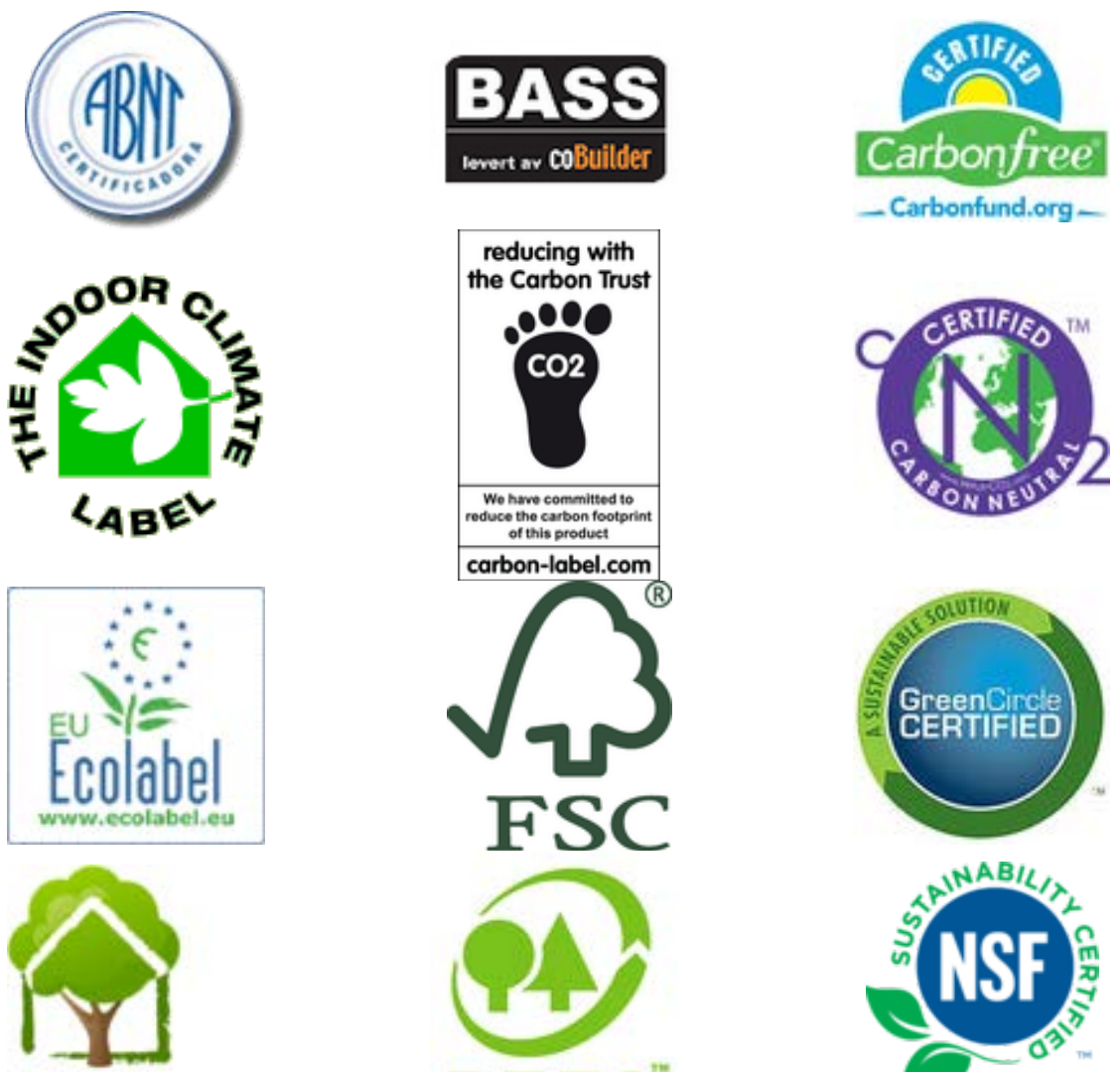

Institut Bauen und Umwelt e.V.
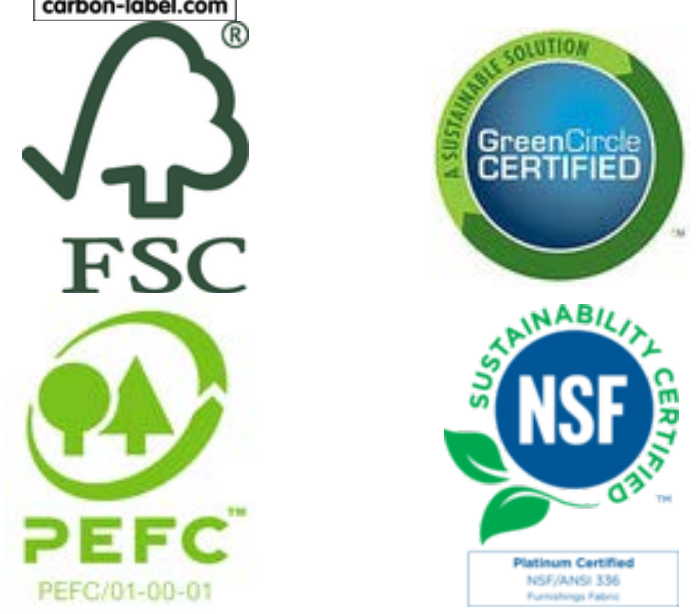

Figure 3 - Some of the eccollabels associations

\section{CONCLUSIONS}

In the building sector, the sustainability approach is an undergoing process with the increasing need of building material certification. The EU standards are having requirements regarding the Ecolabelling of the building materials as a product. However the certification process remains an issue, as soon as there are few regulations regarding the approvals of the certifying associations. With an open market, the main problem is 
$7^{\text {th }}$

INTERNATIONAL CONFERENCE

Contemporary achievements in civil engineering 23-24. April 2019. Subotica, SERBIA

the traceability of a material (product) form the use of natural resources to the end of the product use (building itself or recycling process).

\section{REFERENCES}

[1] Mark L. Brusseau, Ian L. Pepper, Charles Gerba, Environmental and Pollution Science, Academic Press 2019

[2] SR EN ISO 14040:2007, Management de mediu. Evaluarea ciclului de viaţă. Principii şi cadru de lucru

[3] Handbook of Clean Energy Systems, Jinyue Yan (Editor), Publisher: Wiley, 2015

[4] Life Cycle Assessment: Principles and Practice, EPA/600/R-06/060, 2006.

[5] Iyyanki V. Muralikrishna, Valli Manickam, Environmental Management, Science and Engineering for Industry, Butterworth-Heinemann Publishing, 2017

[6] Walter Klöpffer, Mary Ann Curran, "Background and Future Prospects in Life Cycle Assessment”. 